\title{
Community of thermoacidophilic and arsenic resistant microorganisms isolated from a deep profile of mine heaps
}

\author{
S Casas-Flores', EY Gómez-Rodríguez¹ and J V García-Meza²*
}

\begin{abstract}
Soluble arsenic (As) in acidic feed solution may inhibit the copper (Cu) bioleaching process within mine heaps. To clarify the effect of soluble arsenic on the live biomass and bioxidative activity in heaps, toxicological assays were performed using a synthetic feed solution given by a mine company. The microorganisms had previously been isolated from two heap samples at up to $66 \mathrm{~m}$ depth, and cultured using specific media for chemolithotrophic acidophiles ( $\mathrm{pH} 1-2)$ and moderate thermophiles $\left(48^{\circ} \mathrm{C}\right)$, for arsenic tolerance assay. The four media with the highest biomass were selected to assay As-resistance; one culture (Q63h) was chosen to assay biooxidative activity, using a heap sample that contained chalcopyrite and covellite. We found that $0.5 \mathrm{~g} / \mathrm{L}$ of As does not affect living biomass or biooxidative activity on Cu sulfides, but it dissolves $\mathrm{Cu}$, while As precipitates as arsenic acid $\left(\mathrm{H}_{3} \mathrm{AsO}_{4} \cdot 1 / 2 \mathrm{H}_{2} \mathrm{O}\right)$. The arsenic tolerant community, as identified by $16 \mathrm{~S}$ rDNA gene sequence analysis, was composed of three main metabolic groups: chemolithotrophs (Leptospirillum, Sulfobacillus); chemolithoheterotrophs and organoheterotrophs as Acidovorax temperans, Pseudomonas alcaligenes, P. mendocina and Sphingomonas spp. Leptospirillum spp. and S. thermosulfidooxidans were the dominant taxa in the Q63-66 cultures from the deepest sample of the oldest, highest-temperature heap. The results indicated arsenic resistance in the microbial community, therefore specific primers were used to amplify ars (arsenic resistance system), aio (arsenite oxidase), or arr (arsenate respiratory reduction) genes from total sample DNA. Presence of ars $B$ genes in $\mathrm{S}$. thermosulfidooxidans in the Q63-66 cultures permits $\mathrm{H}_{3} \mathrm{AsO}_{4}-\mathrm{As}(\mathrm{V})$ detoxification and strengthens the community's response to As.
\end{abstract}

Keywords: Mine heaps, Bacterial diversity, Extremophiles, Arsenic resistance system

\section{Introduction}

A mine heap is an imposing man-made "deposit" where crushed ore and low-grade minerals are agglomerated and stacked to a height of up to $100 \mathrm{~m}$ and hundreds of meters in length and width. Within such mine heaps, bioleaching processes occur. The commonly used process of bioleaching is feeding a heap with an acidic $(\mathrm{pH}<2)$ "leach solution", to promote chemolithotrophic activity of thermoacidophilic microorganisms living in the heap; the microorganisms then catalyze the solubilization or bioleaching of economically valuable metals, as

\footnotetext{
*Correspondence: jvgm@uaslp.mx

${ }^{2}$ Geomicrobiología, Instituto de Metalurgia, UASLP, Sierra Leona 550,

Lomas 2a 78210, San Luis Potosí, SLP, México

Full list of author information is available at the end of the article
}

$\mathrm{Cu}$ (Rawlings and Johnson 2007). Bioleaching in mine heaps is a widely-employed process used to extract metals from low-grade ores, which would not be economically extracted by any other method.

In a $\mathrm{Cu}$ mine in northwest Mexico, temperatures up to $85^{\circ} \mathrm{C}$ in the mine heap are generated because of the exothermic biooxidation of metal sulfides (MS) as chalcopyrite $\left(\mathrm{CuFeS}_{2}\right)$. Because of the temperatures, thermophiles (moderate, living at $35-60^{\circ} \mathrm{C}$; or extreme, $60-90^{\circ} \mathrm{C}$ ) may be the dominant microorganisms in these mine heaps. Because of the huge spatial-temporal heterogeneity of mine heaps in terms of characteristics as mineral reactivity, irrigation efficiency, temperature, $\mathrm{pH}$, and partial pressure of $\mathrm{O}_{2}, \mathrm{CO}_{2}$, redox potential, dissolved solutes, and available nutrients, considerable diversity of resident acidophilic Archaea and Bacteria is expected, including

\section{望 Springer}

(c) 2015 Casas-Flore et al. This article is distributed under the terms of the Creative Commons Attribution 4.0 International License (http://creativecommons.org/licenses/by/4.0/), which permits unrestricted use, distribution, and reproduction in any medium, provided you give appropriate credit to the original author(s) and the source, provide a link to the Creative Commons license, and indicate if changes were made. 
auto- or heterochemolithotrophs, aerobes, microaerophiles, or anaerobes in the deepest zones (Demergasso et al. 2005; Remonsellez et al. 2009).

However, the mining industry has been concerned about the presence of soluble As(III)/As(V) in feed solution, which may affect the chemolithotrophic microorganisms that inhabit the heaps, thereby affecting the overall $\mathrm{Cu}$ bioleaching process. Soluble As may be present because it is a "chalcophile element" with a low affinity for oxygen, and preferentially bonding to sulfur to form sulfides (Oremland and Stolz 2003). As-containing MS (e.g., arsenopyrite FeAsS, or enargite $\mathrm{Cu}_{3} \mathrm{AsS}_{4}$ ) are common in $\mathrm{Cu}$-sulfide ore deposits. Thus, As-bearing phases are generated, and are present in solid and liquid waste from diverse mining processes, including roasting of the powdered enriched ore (producing fine particle waste), conversion of smelting products (dusts), the solvent extraction process (solutions), Cu recovery by refining (electrolytes), precious metals refinery (purges) and heap leaching [acid mine drainage (AMD)]. The concentration of arsenic in AMD, similar to that of mine heaps, may be from 2 to $20 \mathrm{~g} / \mathrm{L}$ (Santini et al. 2000; Bednar et al. 2002; Delavat et al. 2012a, b).

Some microorganisms are able to use As compounds as electron donors or electron acceptors (Ehrlich 1996), including arsenite $[\mathrm{As}(\mathrm{III})]$ oxidizers and arsenate $[\mathrm{As}(\mathrm{V})]$ reducers, which have been described since 1918, but particularly during the last decade (Battaglia-Brunet et al. 2002, 2006; Dopson et al. 2003; Oremland and Stolz 2003; Baker-Austin et al. 2007; Muller et al. 2007; Bryan et al. 2009; Corsini et al. 2010; Delavat et al. 2012a; Travisany et al. 2012; inter alia). As(III) is more toxic than $\mathrm{As}(\mathrm{V})$. As(III) binds to the thiol groups of proteins, interfering with the function of several enzymes such as pyruvate dehydrogenase and 2-oxo glutarate dehydrogenase (Jackson and Dugas 2003; Oremland and Stolz 2003); As(III) also depletes intracellular glutathione (a tripeptide that acts as antioxidant and protects cells against free radicals), provoking the oxidation of the cytosol (Ehrlich 1996). As(V) acts as a structural analog of phosphate, and replaces the phosphate in cellular processes, inhibiting a plethora of biological phosphate-dependent reactions, including oxidative phosphorylation and production of ATP (Ehrlich 1996; Jackson and Dugas 2003). This explains greater tolerance to As(V) than to As(III): for example, strains of Pseudomonas and Bacillus may tolerate $13 \mathrm{mM} \mathrm{As}(\mathrm{V})$, but only $10 \mathrm{mM} \mathrm{As(III)} \mathrm{(Shakya}$ et al. 2012); similarly, bacteria isolated from an arseniccontaminated river in the Atacama Desert (Chile) are tolerant to $\mathrm{As}(\mathrm{V})$, from 100 to $1,000 \mathrm{mM}$; but only tolerate As(III) in the range of 2-40 mM (Escalante et al. 2009).

Conversely, it is well known that chemolithotrophs can oxidize MS under extreme conditions of $\mathrm{pH}(\mathrm{pH}<3)$, temperature (over $45^{\circ} \mathrm{C}$ ) and metal-rich media, which may contain high concentrations of toxic elements such as As (Rawlings and Johnson 2007). In the acidic $(\mathrm{pH} 3.1)$, geothermal $\left(58-62^{\circ} \mathrm{C}\right)$ springs of Yellowstone National Park (USA), soluble As(III) is oxidized predominantly by microbial mats (Jackson et al. 2001) to amorphous $\mathrm{Fe}(\mathrm{III}) / \mathrm{As}(\mathrm{V})$-rich coprecipitate phases (Langner et al. 2001). At the Carnoulès mine in France, there has been rapid coprecipitation of large amounts of As with $\mathrm{Fe}(\mathrm{III})$ in bacterial mats, as tooeleite $\left[\mathrm{Fe}_{6}\left(\mathrm{AsO}_{3}\right)_{4}-\left(\mathrm{SO}_{4}\right)\right.$ $(\mathrm{OH})_{4} \cdot 4 \mathrm{H}_{2} \mathrm{O}$, mineral ferric arsenite sulfate oxyhydroxide, and amorphous mixed $\mathrm{As}(\mathrm{III}) / \mathrm{As}(\mathrm{V})-\mathrm{Fe}(\mathrm{III})$ oxyhydroxide compounds (Morin et al. 2003).

Arsenic resistance is an important capability for bioleaching microorganisms, because As is released from minerals such as arsenopyrite during bioleaching (Dopson et al. 2003). Over the last decade, many As-resistant microorganisms have been isolated. Specifically, diverse chemolithotrophic As-oxidizers couple the oxidation of As(III) to the reduction of either oxygen (aerobically) or nitrate (anaerobically) and use the energy gained to fix $\mathrm{CO}_{2}$ or bicarbonate $\left(\mathrm{HCO}_{3}{ }^{-}\right)$into organic compounds (Santini et al. 2000; Dopson et al. 2003; Oremland and Stolz 2003; Rhine et al. 2008). Acidithiobacillus ferrooxidans $\mathrm{CC} 1$ precipitated arsenic unexpectedly, as arsenite instead of arsenate (Duquesne et al. 2003).

To elucidate the effect of As on the biooxidative activity of previously isolated communities of chemolithotrophic microorganisms (living biomass) from samples of two mine heaps (northwest Mexico), toxicological and biooxidative assays were performed using a synthetic solution containing As. The isolated biooxidizer and As tolerant microorganisms were identified by $16 \mathrm{~S}$ rDNA sequencing from enriched cultures of the original samples. Because our results indicated the presence of As resistance, putatively because of the presence of ars (the arsenic resistance system gene), aio (arsenite oxidase), or $\operatorname{arr}$ (arsenate respiratory reduction), we searched for the presence of aio, arsB, and arr3 in organisms in the enriched cultures. ArsB and Arr3 are arsenite carrier efflux proteins (Achour et al. 2007; Lett et al. 2012).

\section{Materials and methods}

\section{Sampling and enrichment of microbial cultures}

At a copper $(\mathrm{Cu})$ mine company in Mexico NW, two mine heaps were sampled by drilling a core from the top to $54 \mathrm{~m}$ (heap "T") and $66 \mathrm{~m}$ (heap "Q") depth; composites of ca. $1 \mathrm{~kg}$ were made with samples taken every $9 \mathrm{~m}$. Fifteen samples were obtained in all. Samples were then transferred to sterile plastic bags, which were then sealed.

To make enrichment microbial cultures in order to evaluate As tolerance, two culture media were selected for chemolithoautotrophs and chemolithoheterotrophs. 
From each of the 15 samples, $5 \mathrm{~g}$ was transferred to a test tube containing minimal salt-enriched medium for chemolithoautotrophic acidophiles (living at $\mathrm{pH}$ 1-2) and moderate thermophiles (living at $48^{\circ} \mathrm{C}$ ). Although the mineral samples from the heaps comprise mainly iron sulfurs (pyrite $\mathrm{FeS}_{2}$, and chalcopyrite $\mathrm{CuFeS}_{2}$ ) and sphalerite $(\mathrm{ZnS})$, we decided to use such media to ensure the development of microorganisms. The minimal salt medium was prepared by adding $0.5 \mathrm{~g} / \mathrm{L} \mathrm{MgSO}_{4} \cdot 7 \mathrm{H}_{2} \mathrm{O}$, $0.4 \mathrm{~g} / \mathrm{L}\left(\mathrm{NH}_{4}\right)_{2} \mathrm{SO}_{4}, 0.25 \mathrm{~g} / \mathrm{L} \mathrm{K}_{2} \mathrm{HPO}_{4}$, and $0.1 \mathrm{~g} / \mathrm{L} \mathrm{KCl}$ to distilled water. Finally, $2 \mathrm{~g} / \mathrm{L}$ or $10 \mathrm{mg} / \mathrm{L}$ of $\mathrm{FeSO}_{4} \cdot 7 \mathrm{H}_{2} \mathrm{O}$ were added for autotrophic or heterotrophic growth, respectively. Sulfur (S) sources were omitted, because of the $S$ in the heap samples. For heterotrophic growth, the minimal salt medium was supplemented with yeast extract $(2 \% \mathrm{w} / \mathrm{v})$. The $\mathrm{pH}$ was adjusted to 1.8 with concentrated $\mathrm{H}_{2} \mathrm{SO}_{4}$, and the medium was sterilized at $120^{\circ} \mathrm{C}$ for $20 \mathrm{~min}$. In total, 60 cultures $(15$ samples $\times 2$ cultures, in duplicate) were made.

Tubes were incubated in an orbital shaker at $48^{\circ} \mathrm{C}$ and $170 \mathrm{rpm}$ (Lumistell ${ }^{\mathrm{TM}}$ ). Samples were taken from test tubes once a week, over 3 months, and observed under a Leica DME microscope, with the amount of biomass recorded, evaluating motility (using light microscopy) and the response to 5-ciano-2,3-ditolyl tetrazolium chloride (CTC; using fluorescence microscopy). Culture medium (10-20 mL) was added every week to ensure the continued presence of nutrients. After 3 months, the four cultures that had the highest content of live cells were selected to assay the effect of As on biomass (As tolerance assays). These were the chemolithoautotrophic communities from T27 and T54 (from heap "T", samples obtained at 27 and $54 \mathrm{~m}$ depth, respectively), and the chemolithoheterotrophic communities Q18 and Q63 (heap "Q", at 18 and $63 \mathrm{~m}$ depth, respectively).

\section{As tolerance assays}

Culturing experiments were performed to assess the As tolerance of the selected microbial communities. Triplicate cultures were incubated in test tubes, shaken at $120 \mathrm{rpm}$ and $48^{\circ} \mathrm{C}$, for 7 days. Microorganisms were inoculated into a concentrated, synthetic feed solution that had been obtained from the mining company. The synthetic solution is a mixture of acids solutions and arsenic trioxide $\left(\mathrm{As}_{2} \mathrm{O}_{3}\right)$ that is added to the typical feed solution for the mine heaps.

For the biotic assays, the synthetic solution was diluted to $10 \%$ concentration with minimal salt-enriched medium for autotrophic or heterotrophic growth (recipe given above); final concentrations of $\mathrm{As}$ and $\mathrm{Cu}$ were: 0 (no addition: control assays), or $0.88 \mathrm{~g} / \mathrm{L}$ As (11.7 mM As) and $3.2 \mathrm{~g} / \mathrm{L} \mathrm{Cu}(50 \mathrm{mM} \mathrm{Cu})$ (experimental assays). The $\mathrm{pH}$ was adjusted to 1 with $\mathrm{H}_{2} \mathrm{SO}_{4}$. The dilute synthetic solution also contained $0.24 \mathrm{~g} / \mathrm{L} \mathrm{Fe}$ (in the experimental biotic assays only).

Microbial growth was arbitrarily defined as an increase in observed living (moving) cells, or living biomass. Living biomass was recorded on days 0 (before As and $\mathrm{Cu}$ addition), 4, and 7, based on a previously determined growth curve (that had been obtained from cultures growing without As). The final $\mathrm{As}$ and $\mathrm{Cu}$ concentrations (on day 7) were analyzed with flame atomic absorption spectrophotometers (Perkin-Elmer 2380 and PerkinElmer 1100B).

\section{Biooxidative activity assay}

To assess the biooxidative activity of a microbial community in the presence of As, the chemolithoheterotrophic community Q63h was chosen because of its high biomass production relative to the other cultures. In sterile Erlenmeyer flasks, ca. $1.6 \times 10^{6}$ cells $/ \mathrm{mL}$ from community Q63h were inoculated into minimal growth medium with added yeast extract. A sample from the mine heap Q63 (7\% w/v) was also added. The heap sample had previously been dried for $48 \mathrm{~h}$ under ultraviolet (UV) light, with the sample spread evenly over a crystal surface in a laminar flow cabinet. The dispersed heap sample was shaken every hour to homogenize the exposure of grains. Synthetic solution, containing $\mathrm{As}$ and $\mathrm{Cu}$, was added to the culture medium after the start of the assay to a final concentration of $10 \%$. The final concentrations of As, $\mathrm{Cu}$, and Fe were $0.5,1.69$, and $0.14 \mathrm{~g} / \mathrm{L}$, respectively. The flasks were incubated at $48^{\circ} \mathrm{C}$, rotating at $120 \mathrm{rpm}$, for 21 days. Uninoculated control flasks were also incubated, in triplicate.

Before being added to the culture flasks, the UV-dried heap sample had been analyzed for major mineralogical phases using X-ray diffraction with $\mathrm{Cu}-\mathrm{K} \alpha$ radiation (XRD, Rigaku DMAX 2200; Rigaku program Version 1.3). Mineralogical phases of fine particles $(<2 \mu \mathrm{m})$ were examined using scanning electron microscopy (SEM; Philips XL30) coupled to an energy-dispersive spectroscopy detector (EDS; EDAX DX-4 CDU-LEAP). The detected mineralogy of the heap sample is given in Table 1 . The $\mathrm{pH}$ and soluble $\mathrm{Cu}$ and As of the culture medium were analyzed before and after days 7,14 , and

\section{Table 1 Mineralogy of heap sample Q63-66}

\begin{tabular}{ll}
\hline DRX analysis: Main minerals (>3\%) & $\begin{array}{l}\text { Quartz, } \mathrm{SiO}_{2} \text { Illite, }\left(\mathrm{KH}_{3} \mathbf{0}\right) \\
\mathbf{A l}_{2} \mathrm{Si}_{3} \mathrm{AlO}_{10}(\mathbf{O H})_{2}\end{array}$ \\
\hline SEM analysis: Minor minerals (<3\%) & Chalcopyrite, CuFeS \\
& Covellite, CuS \\
& Fe and Mg oxides \\
& Silicates of Fe, Al, Mg, Na, and K \\
\hline
\end{tabular}


21 of the assay. Living biomass was examined using light microscopy on days 0 (before As addition), 7, 14, and 21 .

\section{PCR amplification of 16S rDNA and generation of clone libraries}

Total genomic DNA extractions from the selected enrichment cultures used for As tolerance assay (T27, T54, Q18h, Q63h); DNA extraction were performed using the harsh lysis method described in Gabor et al. (2003), with minor modification: samples were centrifuged at 3,000 for $15 \mathrm{~min}$ to concentrate biomass, lysis buffer and zircon/silica beads were added to the pellet, and the samples were vortex-agitated for $10 \mathrm{~min}$. Extracted genomic DNA was used as a template for PCR amplifications of the $16 \mathrm{~S}$ rDNA in a total volume of $25 \mu \mathrm{L}$ containing $1 \times$ PCR buffer, $200 \mu \mathrm{M}$ dNTPs, $2.5 \mathrm{mM} \mathrm{MgCl}, 1 \mu \mathrm{M}$ each of forward and reverse oligonucleotide primers, and $1 \mathrm{U}$ of Taq polymerase (Promega). Universal primers 533F and $1492 \mathrm{R}$ were used to amplify bacterial $16 \mathrm{~S}$ rDNA (Bond et al. 2000). Expected amplicon size was approximately 900 bp. Negative controls without DNA were included. A Touch gene Gradient or TC-412 thermocycler (Techne) was used for PCR; with an initial denaturing step at $94^{\circ} \mathrm{C}$ for $5 \mathrm{~min}$; followed by 35 cycles of $94^{\circ} \mathrm{C}$ for $1 \mathrm{~min}, 55^{\circ} \mathrm{C}$ for $1.5 \mathrm{~min}$, and $72^{\circ} \mathrm{C}$ for $2 \mathrm{~min}$; with a final extension step at $72^{\circ} \mathrm{C}$ for $10 \mathrm{~min}$. All PCR products were checked in a $1 \%$ $(\mathrm{w} / \mathrm{v})$ agarose electrophoresis gel in $1 \times$ TAE buffer, poststained with ethidium bromide, and photographed.

Amplicons were cloned according to the manufacturer's protocol in the pGEM-T Easy kit (Promega) and Sangersequenced using an ABI sequencer (Applied Biosystems). Sequences were compared with those in the NCBI database using BLAST (Altschul et al. 1990). A total of 80 clones (20 per culture) were sequenced and identified.

\section{Amplification of genes involved in arsenic resistance} Examining the communities used for the As tolerance assays, four pairs of oligonucleotides were used (Table 2) to attempt to amplify aio, arsB, and/or arr3. Total sample DNA was used as the template in the PCR as described above, using the primer pairs described in Table 2. The PCR had an initial denaturing step at $94^{\circ} \mathrm{C}$ for $5 \mathrm{~min}$; followed by 35 cycles of $94^{\circ} \mathrm{C}$ for $45 \mathrm{~s}, 50^{\circ} \mathrm{C}$ for $45 \mathrm{~s}$, and $72^{\circ} \mathrm{C}$ for $50 \mathrm{~s}$; with a final extension step at $72^{\circ} \mathrm{C}$ for $10 \mathrm{~min}$. All PCR products were checked on a $1 \%(\mathrm{w} / \mathrm{v})$ agarose electrophoresis gel in $1 \times$ TAE buffer, which was post-stained with ethidium bromide and photographed. Amplicons were cloned as previously described.

\section{Phylogenetic analysis}

Sequences were classified using the NCBI Basic Local Alignment Search Tool (BLAST; http://www.ncbi.nlm. nih.gov). Sequences were aligned with those obtained from GenBank, using Clustal W v1.82 (Higgins et al. 1994; http://www.ebi.ac.uk/clustalw). Phylogenetic analyses of $16 \mathrm{~S}$ rDNA and $\operatorname{ars} B$ sequences were done in MEGA4 (Tamura et al. 2007) using neighbor joining (Saitou and Nei 1987); evolutionary distances were computed using the maximum composite likelihood method (Tamura et al. 2004), based on the number of base substitutions per site.

\section{Results}

\section{As tolerance and biooxidative assays}

To select the moderately thermophilic and acidophilic communities that grow best in specific culture media, we examined 3-month-old cultures microscopically. Bacilli were present in $30 \%$ of the analyzed cultures (18 flasks). Four of these cultures, with the highest biomass content, were selected (from heap samples T27, T54, Q18, and Q63; data not shown) to assay the effect of As on biomass.

According to the growth curves calculated for each selected culture, maximum biomass was reached at day 4 (Fig. 1). After 4 days, the biomass of the cultures containing $0.88 \mathrm{~g} / \mathrm{L}$ As $(11.7 \mathrm{mM})$ was not significantly

Table 2 PCR primers for genes that confer resistance to arsenic

\begin{tabular}{lll}
\hline Name & Sequence $\mathbf{5}^{\prime}-\mathbf{3}^{\prime}$ & Gene \\
\hline Primer \#1F & 5'-GTSGGBTGYGGMTAYCABGYCTA-3' & aioB (formerly aoxB) \\
Primer \#1R & 5'-TTGTASGCBGGNCGRTTRTGRAT-3' & arsB \\
darsB1F & 5'-GGTGTGGAACATCGTCTGGAAYGCNAC-3' Inskeep et al. (2007) \\
darsB1R & 5'-CAGGCCGTACACCACCAGRTACATNCC-3' & arr3 (formerly ACR3 1) \\
dacr1F & 5'-GCCATCGGCCTGATCGTNATGATGTAYCC-3' & Achour et al. (2007) \\
dacr1R & 5'-CGGCGATGGCCAGCTCYAAYTTYTT-3' & arr3 (formerly ACR3 2) \\
dacr5F & 5'-TGATCTGGGTCATGATCTTCCCVATGMTGVT-3' & \\
dacr4R & 5'-CGGCCACGGCCAGYTCRAARAARTT-3' &
\end{tabular}

aio arsenite oxidase, ars arsenic resistance system, arr arsenate respiratory-reduction. 


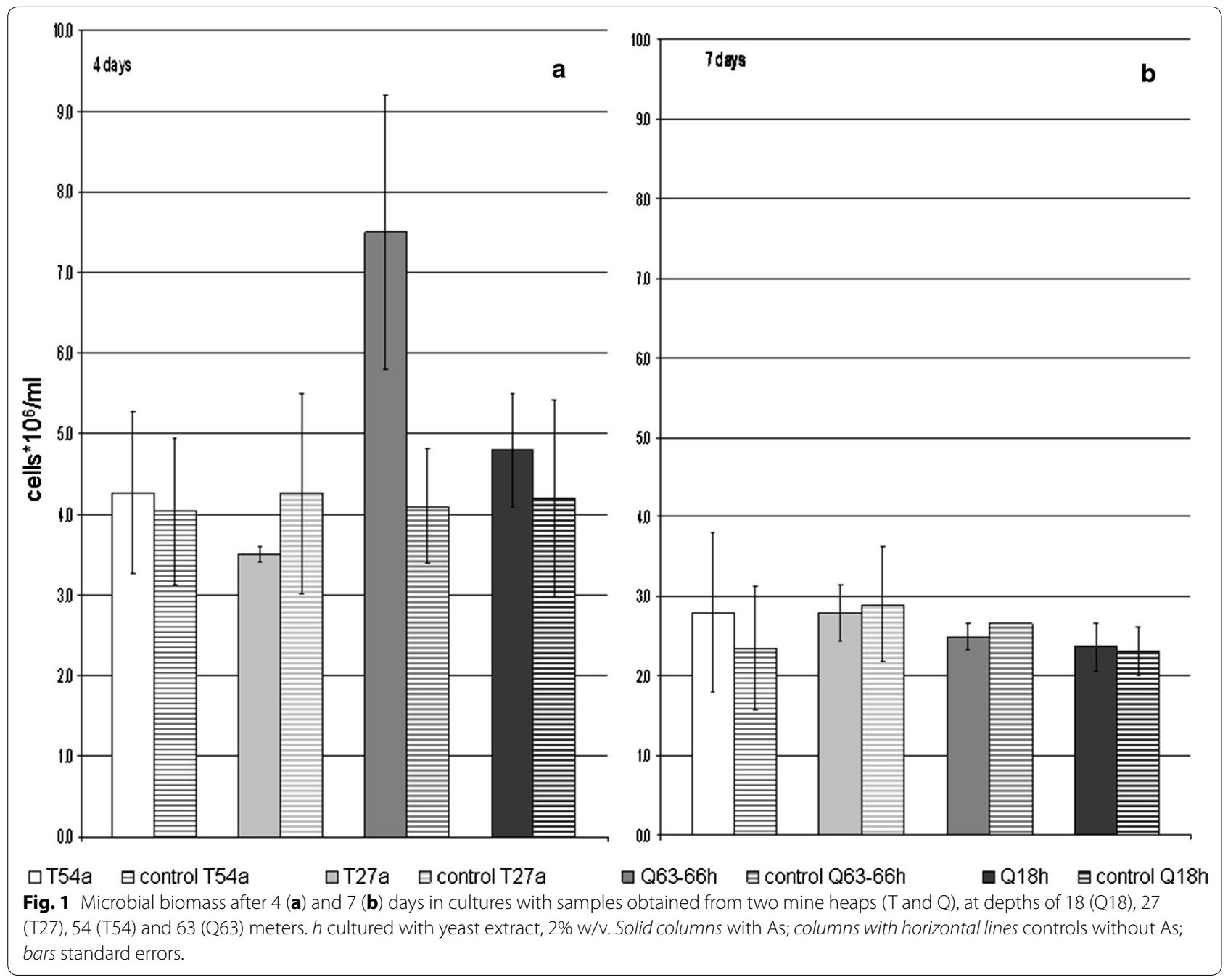

different from that in the controls. The only exception was the Q63 culture, where biomass was significantly higher than in its corresponding control (Fig. 1a). At day 7, biomass decreased both in experimental (with As) and control (without As) cultures, with no significant difference between them (Fig. 1b). The main differences between experimental and control cultures were that in the experimental cultures, the $\mathrm{pH}$ decreased to $<1$, and As-rich precipitate was observed at the bottom of each tube on day 7.

In the tubes prepared for autotrophic growth, the precipitates included copper sulfate, and iron (hydro)oxides wherein As may be adsorbed (Fig. 2a). These cultures also contained arsenic (Fig. 2b).The precipitates of heterotrophic trials contained more particles of copper but fewer of As (Fig. 2c) than in the autotrophic trials.

For the biooxidative assay in the presence of $0.5 \mathrm{~g} / \mathrm{L}$ As (6.7 mM, added to the culture medium), heap sample Q63 was chosen, because no arsenic minerals had been detected therein, but chalcopyrite $\left(\mathrm{CuFeS}_{2}\right)$ and the secondary $\mathrm{Cu}$ mineral, covellite $(\mathrm{CuS}$; Fig. 3; Table 1) had been detected. Notably, microorganisms $\left(\sim 10^{4}\right.$ cells $\left./ \mathrm{mL}\right)$ were observed in the control non-inoculated flasks after 21 days, because the heap sample was not entirely sterilized by UV.

Experimental cultures that had been inoculated with microorganisms from the chemolithoheterotrophic community Q63h, exposed to the heap sample in the presence of As for 21 days, had more $\mathrm{Cu}$ leached $(64.2 \% \mathrm{Cu}$ removed) from $\mathrm{Cu}$ sulfides than the non-inoculated controls (48.7\% Cu removed) (Fig. 4a). Copper leaching is mediated by acidic dissolution of covellite. On day 21, the concentration of soluble As had decreased by $78.6 \%$ in experimental, inoculated flasks, and by $63.4 \%$ in control, non-inoculated flasks (Fig. 4b). These results show that the precipitation of As occurs independently of the biomass present. By day 21 , the $\mathrm{pH}$ had increased slightly, from 1 up to 1.4, while the Eh decreased slightly, from 


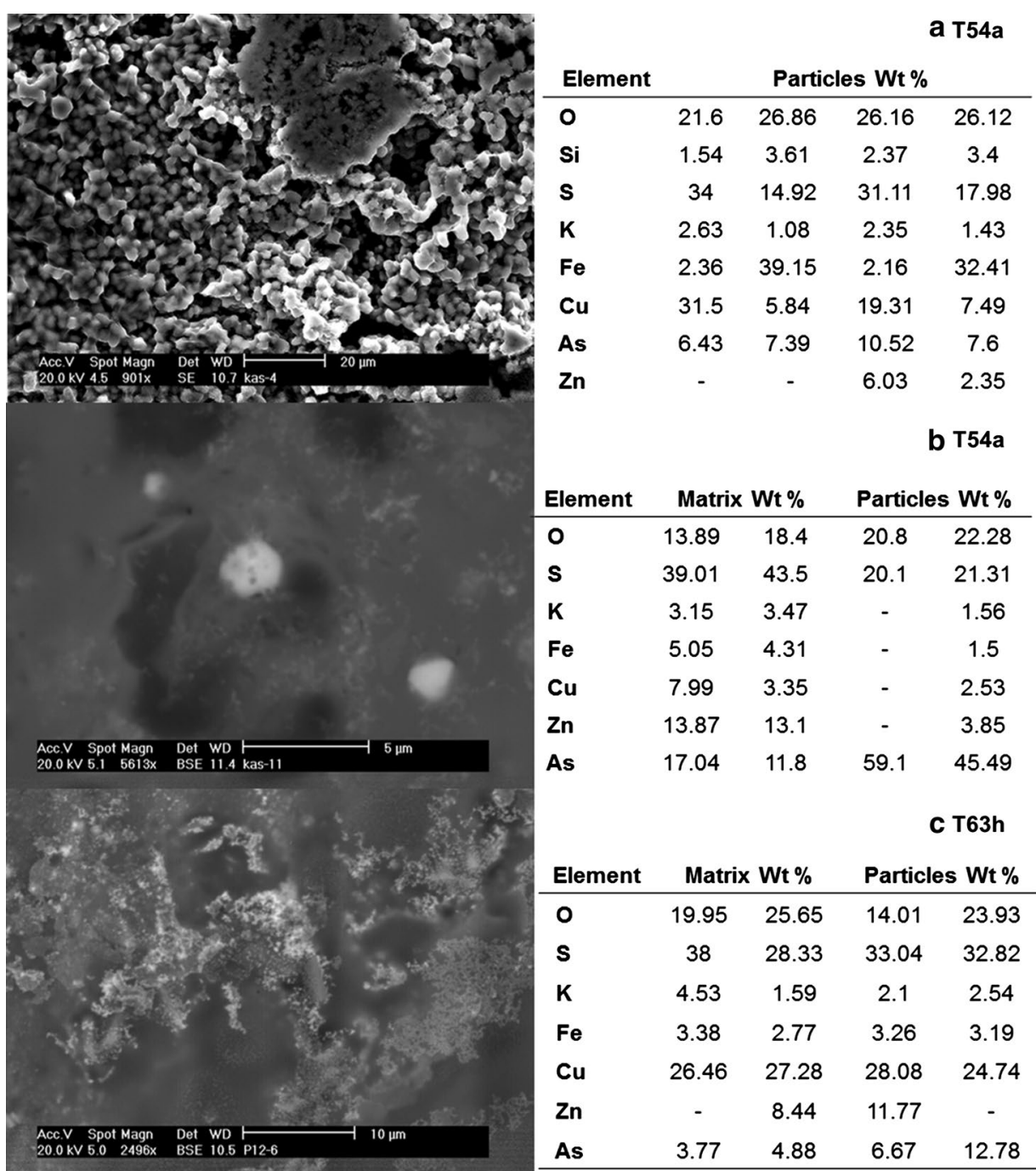

Fig. 2 Scanning electron micrograph and SEM-EDAX analysis of the precipitates formed after 7 days of As tolerance assays, using media for autotrophic (a) and heterotrophic (b) growth. The data show the minimum and maximum As (\%wt) obtained.

700 to $650 \mathrm{mV}$, because of the decrease in Fe(III) concentration. Under these conditions, As precipitates as arsenic acid $\left(\mathrm{H}_{3} \mathrm{AsO}_{4}\right)$.

\section{Microbial community}

To identify the microorganisms used in As tolerance assays, four 16S rDNA libraries were constructed and sequenced from samples T27, T54, Q18h, and Q63h. Table 3 summarizes the samples in which microorganisms were identified as well as the GenBank accession numbers of the BLAST matches.

The microorganisms that were identified belonged to Alphaproteobacteria (e.g., Sphingomonas), Betaproteobacteria (members of Comamonadaceae), Gammaproteobacteria (Bacillus, Aeromonas, Pseudomonas),
Acidobacteria, Nitrospira (Leptospirillum), and Firmicutes (Sulfobacillus, Paenibacillus). BLAST searching returned significant identities with sequences of Sulfobacillus spp. (99\%; GenBank Accession) and Leptospirillum spp. (83\%), microorganisms that are directly responsible for bioleaching; other sequences with significant BLAST matches included Paenibacillus spp. (100\%), Pseudomonas spp. (100\%), Acidobacteria spp. (97\%), Aeromonas spp. (100\%), Sphingomonas spp. (100\%), and a bacterium from Comamonadaceae (100\%). Members of these taxa are commonly found in environments where leaching occurs (Remonsellez et al. 2009).

In the cultures incubated with yeast extract, the only species that grew were Brevibacillus borstelensis and Sphingomonas spp.; while Pseudomonas alcaligenes, $P$. 


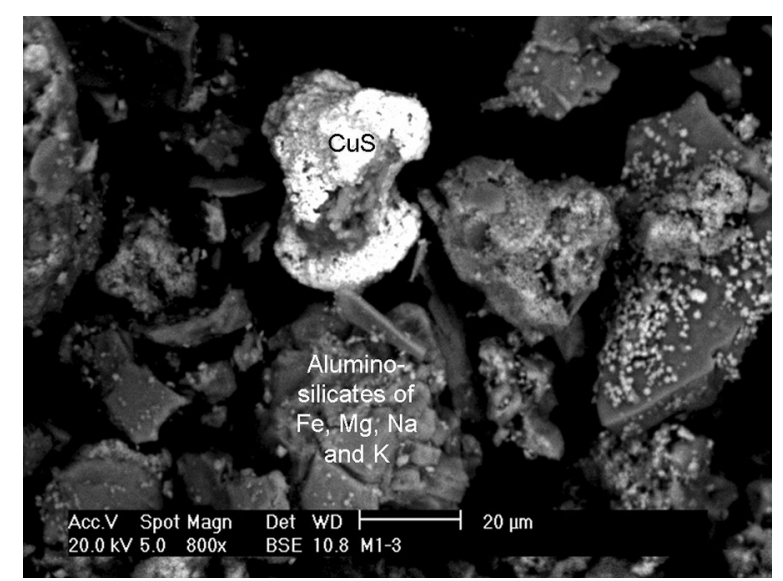

Fig. 3 Scanning electron micrograph and SEM-EDAX analysis of the UV-dried mine heap sample added to Erlenmeyer flasks during the biooxidative assays.

mendocina and Paenibacillus spp. grew in cultures without yeast extract (Table 3).

\section{ars $B$ gene}

The $\operatorname{ars} B$ gene, an As efflux pump, was amplified from DNA samples from Q63h and Q18 communities, using primers darsBIF and darsBIR (Table 2). The sequences obtained were classified, using BLAST, as belonging to Sulfobacillus species, S. thermosulfidooxidans and $S$. acidophilus. Phylogenetic relationships of the ars $B$ sequences (Fig. 5) are consistent with those in the $16 \mathrm{~S}$ rDNA tree (Fig. 6).

\section{Discussion}

The culturable communities of acidophiles and moderate thermophiles that inhabit two mine heaps ("T" and "Q") of a $\mathrm{Cu}$ mine (Mexico NW) are resistant to As, and the presence of soluble As did not affect the ongoing bioleaching of $\mathrm{Cu}$ from chalcopyrite and covellite, as shown by the results of the biooxidative assays.

The biooxidative assays were performed using the culture derived from Q63-66, the deepest, highest-temperature sample, because this contained the most living biomass in the As-tolerance assays (Fig. 1). In this culture, the chemolithotrophs Leptospirillum spp. and $S$. thermosulfidooxidans were the dominant species. Both species are As-resistant (Watling et al. 2008; Dopson and Holmes 2014), and arsB has previously been identified in Sulfobacillus (van der Merwe et al. 2010). arsB drives efflux of As(III) through the cell membrane, via membrane potential (Gihring et al. 2003; Dopson et al. 2003; Slyemi and Bonnefoy 2012).

We propose that the presence of ars $B$ genes from $S$. thermosulfidooxidans in the Q63-66 community (Fig. 5) strengthens the response to As. The cultures

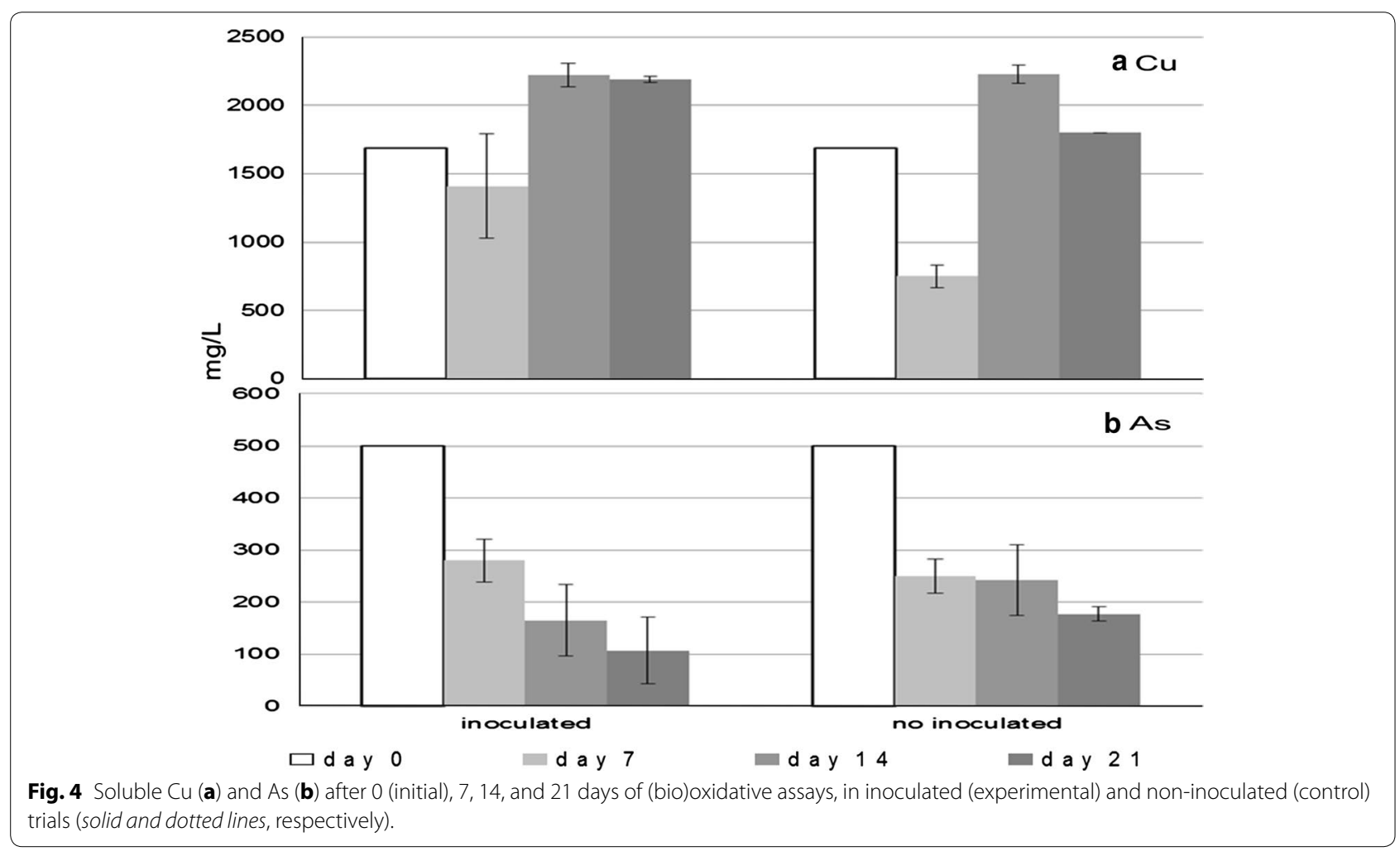


Table 3 Classification based on BLAST results of bacterial 16S rRNA sequences present in enriched cultures

\begin{tabular}{|c|c|c|}
\hline Microorganism & Comments & Heap (frequency) \\
\hline Acidobacteria bacterium sp. ${ }^{a}$ & $\begin{array}{l}\text { Chemoorganotrophic; from acidic mineral environment; non-cultured soil bacte- } \\
\text { rium present in radionuclide- and metal-contaminated environments }\end{array}$ & T27 (1), Q63-66h (5) \\
\hline Acidovorax temperans & $\begin{array}{l}\text { Type strain CB2; isolated from an activated sludge wastewater treatment plant in } \\
\text { northern New Zealand; forms biofilms, promotes flocculation, removes phospho- } \\
\text { rous }\end{array}$ & $\mathrm{T} 27(2)$ \\
\hline Acidovorax spp. ${ }^{\text {a }}$ & $\begin{array}{l}\text { Strain JS42; from soil; aerobic; capable of degrading toxic nitroaromatic compounds } \\
\text { and polyethylene; As resistance }\end{array}$ & $\mathrm{T} 54(2)$ \\
\hline Bacillus spp. & Widely distributed bacterium; highly resistant to As(III) & Q63-66h (1) \\
\hline Brevibacillus borstelensis & $\begin{array}{l}\text { From soil; thermophilic; lipolytic; degrades polyethylene as C source; in acidic soil } \\
\text { waste; previously described in leaching ponds in Cananea Mine, Mexico }\end{array}$ & $\mathrm{T} 54 \mathrm{~h}(2)$ \\
\hline Leptospirillum ferriphilum ${ }^{a}$ & $\begin{array}{l}\text { AMD; bioleaching tank for polymetallic (Cu, Zn and Fe sulfides) concentrates; mine } \\
\text { heaps and leaching (pregnant solution) ponds; previously described in leaching } \\
\text { ponds of Cananea Mine, Mexico; As resistance }\end{array}$ & Q63-66 (1) \\
\hline Leptospirillum spp. ${ }^{a}$ & $\begin{array}{l}\text { Bioleaching tanks, mine heaps and bioleaching (pregnant solution) ponds; Ni mine } \\
\text { tailings; As resistance }\end{array}$ & $\mathrm{T} 27(2), \mathrm{T} 54(2), \mathrm{Q} 63-66(3)$ \\
\hline Paenibacillus spp. & $\begin{array}{l}\text { P. polymyxa has been studied for bioflotation and bioflocculation; as a soil inoculant } \\
\text { in agriculture and horticulture; reported in rock varnish; fixes N; degrades cel- } \\
\text { lulose; some species reduce nitrate; As resistance }\end{array}$ & $\mathrm{T} 27$ (1), T54 (2), Q63-66h (2) \\
\hline Pseudomonas alcaligenes & $\begin{array}{l}\text { Widely distributed; used as soil inoculant for bioremediation purposes; degrades } \\
\text { polycyclic aromatic hydrocarbons }\end{array}$ & T27 (1), T54 (2), Q63 (2) \\
\hline $\begin{array}{l}\text { P. mendocina } \\
\text { HQ113219.1 }\end{array}$ & $\begin{array}{l}\text { Anaerobic; solubilizes Fe minerals; from soil enrichment with ethanol; degrades } \\
\text { acyclic isoprenoids; As resistance }\end{array}$ & $\mathrm{T} 54(2)$ \\
\hline Pseudomonas spp. & Anaerobic; As resistance & Q18h, T54 (2) \\
\hline P. pseudoalcaligenes & Widely distributed; anaerobic; from soil; uses cyanide as N source & T27 (1), T54 (1), Q63-66 \\
\hline Sphingomonas spp. & $\begin{array}{l}\text { Chemoheterotrophic; strictly aerobic; some degrade chlorinated dibenzofurans and } \\
\text { dibenzo-p-dioxins; reduces } \mathrm{As}(\mathrm{V}) \text { via arsC; Cu tolerant }\end{array}$ & Q18h (1), Q63-66h (2) \\
\hline Sulfobacillus acidophilus & $\begin{array}{l}\text { Mixotrophic; } \mathrm{Fe}^{3+} \text { reducer; yeast extract as an electron source; geothermal and } \\
\text { sulfur-rich environments }\end{array}$ & Q18h (1) \\
\hline Sulfobacillus sp. $1^{\text {a }}$ and sp. 2 & $\begin{array}{l}\text { Mixotrophic for organic compounds (such as yeast extract); AMD; mine heaps; } \\
\text { bioleaching tanks for polymetallic concentrates; As tolerant }\end{array}$ & Q18h, sp. 1 (5); Q63-66 (h), sp. 2 (1) \\
\hline S. thermosulfidooxidans & $\begin{array}{l}\text { Mixotrophic; geothermal environments; carbon deposits bioleaching tanks of pyrite, } \\
\text { Co-pyrite, arsenopyrite, chalcopyrite and chalcocite; mine heaps and leaching } \\
\text { ponds; As tolerant }\end{array}$ & Q18h (12), T27 (8), Q63-66h (13) \\
\hline
\end{tabular}

$h$ cultured with yeast extract, $2 \% \mathrm{w} / \mathrm{v}$.

a Non-cultivable species (NCBI).

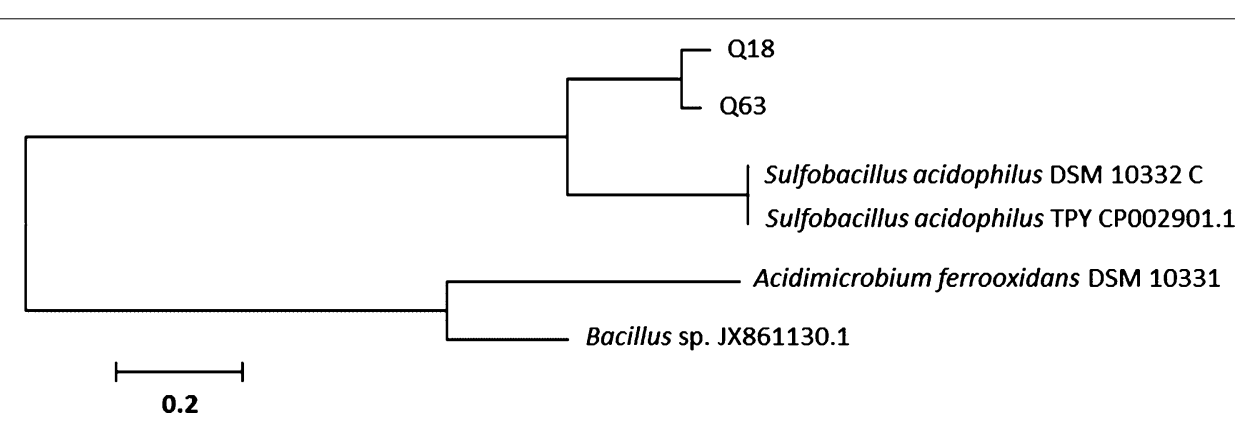

Fig. 5 Maximum parsimony tree of ars $B$ Permease sequences. The optimal tree with the sum of branch lengths $=2.73$ is shown. The tree is drawn to scale, with branch lengths in the same units as those of the evolutionary distances used to infer the phylogenetic tree. The evolutionary distances are in the units of the number of base substitutions per site. All sequenced codon positions were included in the alignment, for introns and exons in arsB; however, every site containing gaps or missing data was then eliminated from the dataset. There were a total of 707 positions in the final dataset. ars $B$ genes from different bacteria were used as indicated in the tree by their name, followed by the GenBank accession numbers. The consensus sequences of Q18 and Q63 samples were used to construct the tree. 


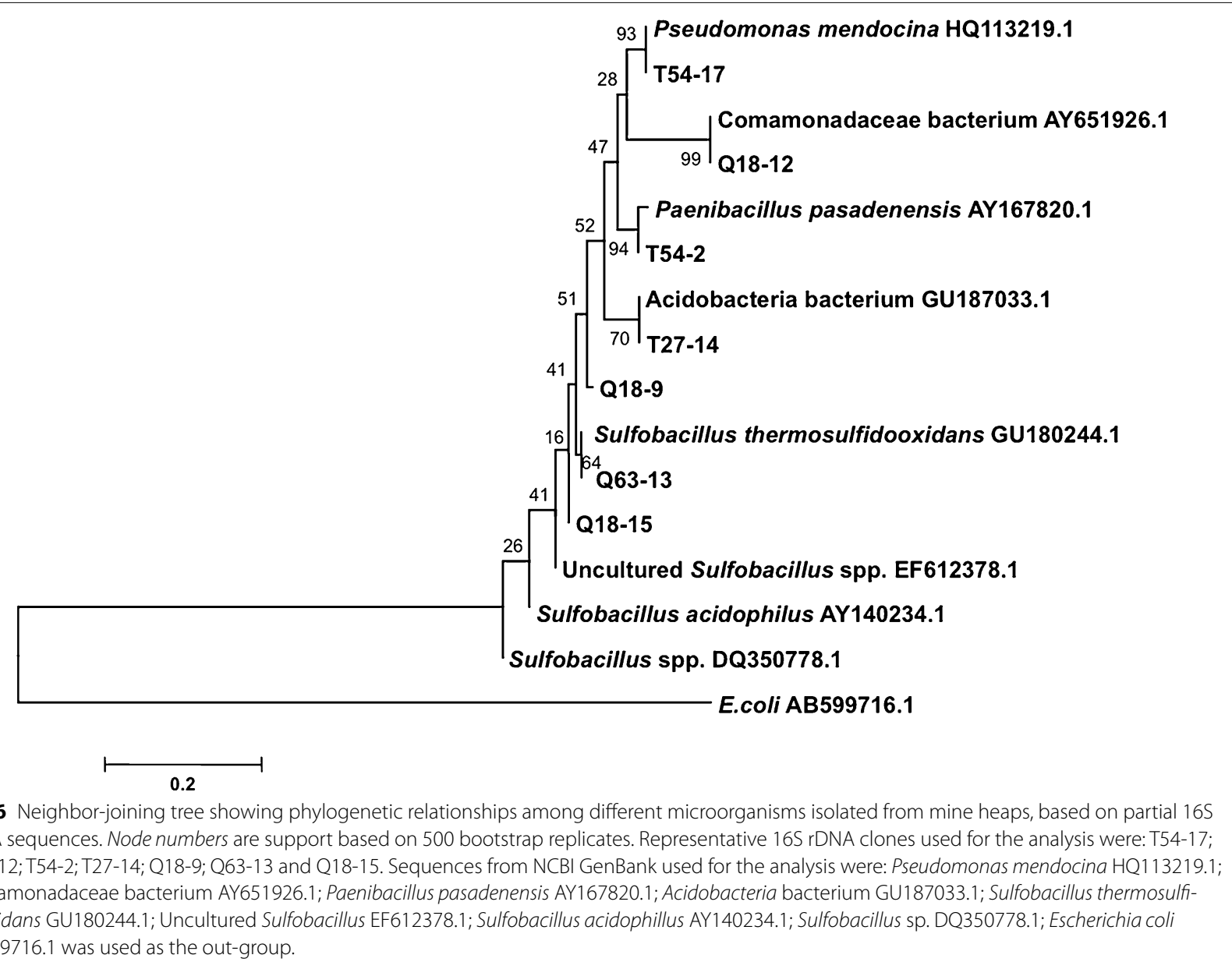

used for As tolerance assays contained arsenic acid (e.g., $\mathrm{H}_{3} \mathrm{AsO}_{4}$; Fig. 2b) formed from arsenic oxide, because of the prevalent oxidizing (Eh up to 1,000 $\mathrm{mV} / \mathrm{SHE}$ ) and acidic ( $\mathrm{pH} 0.9-1.2)$ conditions during the assays (Ferguson and Gavis 1972). Thus, the response to As is likely via $\mathrm{H}_{3} \mathrm{AsO}_{4}-\mathrm{As}(\mathrm{V})$ detoxification, using the reduction of $\mathrm{As}(\mathrm{V})$ to soluble As(III) through the oxidation of dissolved $\mathrm{HS}^{-}$, both of which are processes mediated by microorganisms (Andrade et al. 2010; Eq. 1).

$$
4 \mathrm{HAsO}_{4}^{2-}+\mathrm{HS}^{-}+7 \mathrm{H}^{+} \rightarrow 4 \mathrm{H}_{3} \mathrm{AsO}_{3}^{0}+\mathrm{SO}_{4}^{2-}
$$

Because of the prevalent oxidizing (Eh $>640 \mathrm{mV}$ ) and acidic $(\mathrm{pH}<1.0)$ conditions in both assays (As tolerance and biooxidative), $\mathrm{As}(\mathrm{V})$ is the dominant arsenic species that would form mixed and amorphous $\mathrm{As}(\mathrm{V})-$ $\mathrm{Fe}(\mathrm{III})$ oxy-hydroxides, provided enough $\mathrm{Fe}(\mathrm{II})$ oxidizes (Morin et al. 2003). In cells, As(V) detoxification involves its enzymatic reduction to As(III) in the cytoplasm by arsenate reductase arsC; $\mathrm{As}(\mathrm{III})$ is then pumped out of the cell by ArsB (Slyemi and Bonnefoy 2012), and may precipitate into the medium via reactions catalyzed by microorganisms (Leblanc et al. 1996; Bednar et al. 2002; Casiot et al. 2003; Morin et al. 2003); arsenic acid was detected after the As-tolerance assays only in inoculated tubes (Fig. 2). As(III) may also be sequestered outside the cell in its extracellular polymers, in which the $\mathrm{Fe}(\mathrm{II})$ oxidation site also serves as the $\mathrm{As}(\mathrm{III})$ nucleation site (Muller et al. 2007; Slyemi and Bonnefoy 2012).

Notably, at the end of the As-tolerance experiment, the precipitates in tubes for heterotrophic growth contained less arsenic (Fig. 2c) than those in the tubes for autotrophic growth (Fig. 2b). This is likely because of reductive dissolution of iron (hydr)oxides by labile organic matter (Andrade et al. 2010), e.g., the yeast extract added to the heterotrophic tubes; or because of the predominance of Leptospirillum spp. in autotrophic cultures and the presence of Sulfobacillus spp. only in heterotrophic cultures.

The ferrooxidizers Leptospirillum ferriphilum and Leptospirillum spp. (Table 3) are strictly chemolithoautotrophic, and they were detected primarily in cultures for autotrophic growth and in samples from depths greater 
than $27 \mathrm{~m}$. Leptospirillum is a common genus present in bioleaching tanks, mine heaps and bioleaching (pregnant liquor solution) ponds (Tuffin et al. 2006; Remonsellez et al. 2009) where its role in the community is crucial as Leptospirillum fixes $\mathrm{CO}_{2}$ and oxidizes $\mathrm{NH}_{4}{ }^{+}$, providing $\mathrm{C}$ and $\mathrm{N}$ sources to the rest of the microbial community. The "carbon fixation rates in $\sim 100 \mathrm{~mm}$ thick biofilms from AMD are broadly equivalent to those achieved across the ocean photic zone" (Denef et al. 2010). Leptospirillum also generates energy and Fe(III) through Fe(II) oxidation, triggering an Eh decrease that drives arsenic precipitation at $\mathrm{pH} \sim 1.0$.

Meanwhile, Sulfobacillus was the most common genus detected in cultures obtained from heap samples (34 clones), independent of their depth of the samples within the heap $(18,27,54$, or $63 \mathrm{~m})$. Sulfobacillus was the unique genus recovered from cultures Q18h, and was the dominant genus recovered from cultures Q63h (h: with yeast extract). The only ars $B$ sequences present in the sample are those of Sulfobacillus (Fig. 5).

Recently, Acosta et al. (2014) extracted RNA from the pregnant liquor solution samples, also found that Leptospirillum and S. thermosulfidooxidans are the most abundant thermoacidophiles in the deeper areas of heaps (up to $54 \mathrm{~m}$ ); their relative abundance increases with the age of the heap, and where there is $\mathrm{pH}$ lower than 2, high Eh, and up to $3 \mathrm{~g} / \mathrm{L}$ of $\mathrm{Cu}$ (Demergasso et al. 2005; Remonsellez et al. 2009). Similar conditions were present in our experiments of As tolerance and biooxidation, while temperature was $48^{\circ} \mathrm{C}$

Although the identified microorganisms from cultures comprise nine genera of bacteria, only two genera, Leptospirillum and Sulfobacillus, are chemolithotrophs typically found un mine heaps or bioleaching tanks. The diversity of microbes detected here in mine heaps includes other metabolic functional groups of bacteria, some of them previously described in mining environments and geothermal areas (Table 3), including sequences from Pseudomonas spp. (8 clones), Acidobacteria spp. (6 clones), and Paenibacillus spp. (5 clones). Rawlings and Johnson (2007) have found that despite the significant (low) diversity of microorganisms inhabiting mine heaps, relatively few taxa play a major role in biomining processes. These bacteria may indirectly affect the overall MS bioleaching process via biological interactions (symbiosis) with the MS biooxidizers, as has been suggested by Watling et al. (2008); e.g., the firmicute Paenibacillus could potentially use sulfur and iron compounds as an energy source (Bond et al. 2000). Paenibacillus Q8 has polymer-degrading enzymes that confer it cellulolytic, hemicellulolytic and amylolytic activities under a broad $\mathrm{pH}$ range (4-10) and under high $\mathrm{As}(\mathrm{III})$ and $\mathrm{As}(\mathrm{V})$ concentrations (up to 750 and 1,000 mg/L, respectively) (Delavat et al. 2012b).
Interestingly, most of the microorganisms identified in our work can degrade different complex organic compounds (Leys et al. 2004; Hadad et al. 2005; Delavat et al. 2012b). These include Acidovorax spp. (degrading toxic nitroaromatic compounds), Brevibacillus borstelensis (polyethylene), Pseudomonas alcaligenes (polycyclic aromatic hydrocarbons), P. mendocina (acyclic isoprenoids), Paenibacillus spp. (sugar monomers and some polymers including hemicellulose, cellulose, and starch), and Sphingomonas spp. (chlorinated dibenzofurans and dibenzop-dioxins) (Table 3). The presence of such degradative metabolic capabilities in the organisms cultured from our samples may partially be explained by the disposal of organic solvents, such as kerosene-based solvents (from the "solvent extraction process") into the heaps.

The main metabolic groups of $\mathrm{Cu}$ - and As-tolerant microorganisms detected in our cultures communities from mine heap samples are: (1) chemolithoautotrophs, employing oxidation of $\mathrm{Fe}^{2+}$ or reduced S-compounds (Leptospirillum or Sulfobacillus, respectively); (2) chemolithoheterotrophs, employing reduction of $\mathrm{Fe}^{3+}$ in microaerophilic conditions (Sulfobacillus); and (3) aerobic or anaerobic organoheterotrophs (Acidovorax, Brevibacillus borstelensis, Pseudomonas alcaligenes, P. mendocina, Paenibacillus and Sphingomonas). The same metabolic groups have previously been described by Baker and Banfield (2003) AMD, and it was suggested that a subset of the detected microorganisms could fix the nitrogen required by the community. Leptospirillum ferriphilum and Paenibacillus fix nitrogen (Table 3; Xie et al. 2011). The metabolic capabilities of the communities cultured from mine heaps (carbon and nitrogen fixation, aerobic and anaerobic carbon degradation, sulfur and iron oxidation, microaerophilic iron reduction, arsenic and $\mathrm{Cu}$ resistance) increase the community's functional robustness. Xie et al. (2011) also reported similar common metabolic capabilities in five different AMDs from $\mathrm{Cu}$ mines. The coexistence of microorganisms with different environmental requirements (such as oxygen) in mine heaps is because some occur as biofilms on the surface (García-Meza et al. 2010).

Delavat et al. (2012b) suggested that "AMDs could be considered as reservoir of genes with potential biotechnological properties". We share this conclusion for microorganisms resident in mine heaps as described here, with their various metabolic capabilities (Table 3). These could be used to implement solutions to environmental pollution problems associated with mining or other activities. Examples could include phosphorus removal by Acidovorax temperans; polyethylene degradation by Acidovorax spp. and Brevibacillus borstelensis; cyanide degradation by Pseudomonas pseudoalcaligenes, or chlorinated dibenzofuran and dibenzo- $p$-dioxin degradation by Sphingomonas spp.

In this work, Leptospirillum and Sulfobacillus were the only chemolithotrophs identified using the prepared 
cultures. Culturing was necessary for the assays performed; but it is indispensable to sequence directly from samples, as well as to combine geochemical, biochemical and microbiological techniques, especially the GeoChips and omics approaches, to gain more comprehensive knowledge of the active microbial functions within this manmade ecosystem and their response to As.

To elucidate the effect of As on the biooxidative activity of previously isolated communities of chemolithotrophic microorganisms (living biomass) from samples of two mine heaps (northwest Mexico), toxicological and biooxidative assays were performed using a synthetic solution containing As. The isolated biooxidizer and As tolerant microorganisms were identified by $16 \mathrm{~S}$ rDNA sequencing from enriched cultures of the original samples. Because our results indicated the presence of As resistance, putatively because of the presence of ars (the arsenic resistance system gene), aio (arsenite oxidase), or $\operatorname{arr}$ (arsenate respiratory reduction), we searched for the presence of aio, $\operatorname{ars} B$, and $\operatorname{arr} 3$ in organisms in the enriched cultures. ArsB and Arr3 are arsenite carrier efflux proteins (Achour et al. 2007; Lett et al. 2012).

This paper describes for the first time microorganisms isolated from mine heaps samples of $63 \mathrm{~m}$ depth. The culturable communities includes relatively few taxa playing a major role in MS biooxidation, as Sulfobacillus spp. and Leptospirillum spp. The other bacteria may indirectly affect the overall MS bioleaching process via biological interactions with the MS biooxidizers. The isolated are As tolerant microorganisms, but the only ars $B$ sequences present in the sample are those of Sulfobacillus, while Leptospirillum oxidize $\mathrm{Fe}(\mathrm{II})$ triggering an Eh decrease that drives arsenic precipitation at $\mathrm{pH} \sim 1.0$. According to the literature review, most of the cultivable and identified microorganisms are reservoir of genes with potential biotechnological properties.

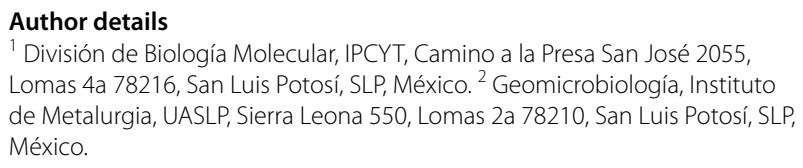

\section{Acknowledgements}

The authors thank Karen Torres Cázares of the Laboratory of Geomicrobiology, UASLP and María Isabel Isordia Jasso of the División de Biología Molecular (IPICyT), for their continued support in the experimental work. We thank our reviewers for helping us to improve our manuscript.

\section{Compliance with ethical guidelines}

\section{Competing interests}

The authors declare that they have no competing interests.

Received: 13 July 2015 Accepted: 17 July 2015

Published online: 19 August 2015

\section{References}

Achour A, Bauda P, Billard P (2007) Diversity of arsenite transporter genes from arsenic-resistant soil bacteria. Res Microbiol 158:128-137. doi:10.1016/j. resmic.2006.11.006

Acosta M, Galleguillos P, Ghorbani Y, Tapia P, Contador Y, Velásquez A et al (2014) Variation in microbial community from predominantly mesophilic to thermotolerant and moderately thermophilic species in an industrial copper heap bioleaching operation. Hydrometallurgy 150:281-289. doi:10.1016/j.hydromet.2014.09.010

Altschul SF, Gish W, Miller W, Myers E, Lipman DJ (1990) Basic local alignment search tool. J Mol Biol 215(3):403-410. doi:10.1016/ S0022-2836(05)80360-2

Andrade CF, Jamieson HE, Kyser TK, Praharaj T, Fortin D (2010) Biogeochemical redox cycling of arsenic in mine-impacted lake sediments and coexisting pore waters near Giant Mine, Yellowknife Bay, Canada. Applied Geochem 25:199-211. doi:10.1016/j.apgeochem.2009.11.005

Baker JB, Banfield JF (2003) Microbial communities in acid mine drainage. FEMS Microbiol Ecol 44:139-152. doi:10.1016/S0168-6496(03)00028-X

Baker-Austin C, Dopson M, Wexler M, Sawers RG, Stemmler A, Rosen BP et al (2007) Extreme arsenic resistance by the acidophilic archaeon 'Ferroplasma acidarmanus' Fer1. Extremophiles 11:425-434. doi:10.1007/ s00792-006-0052-Z

Battaglia-Brunet F, Dictor MC, Garrido F, Crouzet C, Morin D, Dekeyser Ket al (2002) An arsenic(III)-oxidizing bacterial population: selection, characterization, and performance in reactors. J Appl Microbiol 93:656-667. doi:10.1046/j.1365-2672.2002.01726.x

Battaglia-Brunet F, Joulian C, Garrido F, Dictor MC, Morin D, Coupland K et al (2006) Oxidation of arsenite by Thiomonas strains and characterization of Thiomonas arsenivorans sp. nov. Antonie Van Leeuwenhoek 89:99-108. doi:10.1007/s10482-005-9013-2

Bednar AJ, Garbarino JR, Ranville JF, Wildeman TR (2002) Preserving the distribution of inorganic arsenic species in groundwater and acid mine drainage samples. Environ Sci Technol 36:2213-2218. doi:10.1021/es0157651

Bond PL, Smriga SP, Bandfield JF (2000) Phylogeny of microorganisms populating a thick, subaerial, predominantly lithotrophic biofilm at an extreme acid mine drainage site. Appl Environ Microbiol 66:3842-3849. doi:10.1128/AEM.66.9.3842-3849.2000

Bryan CG, Marchal M, Battaglia-Brunet F, Kugler V, Lemaitre-Guillier C, Lièvremont D, Bertin PN, Arsène-Ploetze F (2009) Carbon and arsenic metabolism in Thiomonas strains: differences revealed diverse adaptation processes. BMC Microbiol 9:127. doi:10.1186/1471-2180-9-127

Casiot C, Morin G, Juillot F, Bruneel O, Personné J-C, Leblanc M et al (2003) Bacterial immobilization and oxidation of arsenic in acid mine drainage (Carnoulès creek, France). Water Res 37:2929-2936. doi:10.1016/ S0043-1354(03)00080-0

Corsini A, Cavalca L, Crippa L, Zaccheo P, Andreoni V (2010) Impact of glucose on microbial community of a soil containing pyrite cinders: role of bacteria in arsenic mobilization under submerged condition. Soil Biol Biochem 42:699-707. doi:10.1016/j.soilbio.2009.12.010

Delavat F, Lett MC, Lièvremont D (2012a) Novel and unexpected bacterial diversity in an arsenic-rich ecosystem revealed by culture-dependent approaches. Biol Direct 7:28. doi:10.1186/1745-6150-7-28

Delavat F, Phalip V, Forster A, Lett MC, Lièvremont D (2012b) Deciphering the role of Paenibacillus strain Q8 in the organic matter recycling in the acid mine drainage of Carnoulès. Microb Cell Fact 11:16. doi:10.1186/1475-2859-11-16

Demergasso CS, Galleguillos PA, Escudero LG, Zepeda VJ, Castillo D, Casamayor EO (2005) Molecular characterization of microbial populations in a lowgrade copper ore bioleaching test heap. Hydrometallurgy 80(4):241-253. doi:10.1016/j.hydromet.2005.07.013

Denef VJ, Mueller RS, Banfield JF (2010) AMD biofilms: using model communities to study microbial evolution and ecological complexity in nature. ISME J 4:599-610. doi:10.1038/ismej.2009.158

Dopson M, Holmes DS (2014) Metal resistance in acidophilic microorganisms and its significance for biotechnologies. Appl Microbiol Biotechnol 98:8133-8144. doi:10.1007/s00253-014-5982-2

Dopson M, Baker-Austin C, Koppineedi PR, Bond PL (2003) Growth in sulfidic mineral environments: metal resistance mechanisms in acidophilic microorganisms. Microbiol 149:1959-1970. doi:10.1099/mic.0.26296-0 
Duquesne K, Lebrun S, Casiot C, Bruneel O, Personné JC, Leblanc M et al (2003) Immobilization of arsenite and ferric iron by Acidithiobacillus ferrooxidans and its relevance to acid mine drainage. Appl Environ Microbiol 69(10):6165-6173. doi:10.1128/AEM.69.10.6165-6173.2003

Ehrlich HL (1996) Geomicrobiology, 3rd edn. M Dekker, New York

Escalante G, Campos VL, Valenzuela C, Yanez J, Zaror C, Mondaca MA (2009) Arsenic resistant bacteria isolated from arsenic contaminated river in the Atacama Desert (Chile). Bull Environ Contam Toxicol 83:657-661. doi:10.1007/s00128-009-9868-4

Ferguson JF, Gavis J (1972) A review of the arsenic cycle in natural waters. Water Res 6:1259-1274

Gabor EM, de Vries EJ, Janssen DB (2003) Efficient recovery of environmental DNA for expression cloning by indirect extraction methods. FEMS Microb Ecol 44:153-163. doi:10.1016/S0168-6496(02)00462-2

García-Meza JV, Lara-Castro RH, Casas-Flores S (2010) Biofilms and mining: micro-organisms behind macro-mining processes. In: Loreido A (ed) Bacterial populations: basic and applied aspects of their structure and evolution. Research Signpost, Trivandrum, Kerala, pp 117-141

Gihring TM, Bond PL, Peters SC, Banfield JF (2003) Arsenic resistance in the archaeon "Ferroplasma acidarmanus": new insights into the structure and evolution of the ars genes. Extremophiles 7(2):123-130. doi:10.1007/ s00792-002-0303-6

Hadad D, Geresh S, Sivan A (2005) Biodegradation of polyethylene by the thermophilic bacterium Brevibacillus borstelensis. J Appl Microbiol 98(5):1093-1100. doi:10.1111/j.1365-2672.2005.02553.x

Higgins D, Thompson J, Gibson T, Thompson JD, Higgins DG, Gibson TJ (1994) CLUSTAL W: improving the sensitivity of progressive multiple sequence alignment through sequence weighting, position-specific gap penalties and weight matrix choice. Nucleic Acids Res 22:4673-4680. http://www. ebi.ac.uk/clustalw/

Inskeep WP, Macur RE, Hamamura N, Warelow TP, Ward SA, Santini JM (2007) Detection, diversity and expression of aerobic bacterial arsenite oxidase genes. Environ Microbiol 9(4):934-943. doi:10.1111/j.1462-2920.2006.01215.x

Jackson CR, Dugas SL (2003) Phylogenetic analysis of bacterial and archaeal ars $C$ gene sequences suggests an ancient, common origin for arsenate reductase. BMC Evol Biol 3:1-10. doi:10.1186/1471-2148-3-18

Jackson CR, Langner HW, Donahoe-Christiansen J, Inskeep WP, McDermott TR (2001) Microbial community in an arsenite-oxidizing hot spring. Environ Microbiol 3:532-542. doi:10.1046/j.1462-2920.2001.00221.x

Langner HW, Jackson CR, McDermott TR, Inskeep WP (2001) Rapid oxidation of arsenite in a hot spring ecosystem, Yellowstone National Park. Environ Sci Technol 35:3302-3330. doi:10.1021/es0105562

Leblanc M, Achard B, Othman D, Luck JM (1996) Accumulation of arsenic from acidic mine waters by ferruginous bacterial accretions (stromatolites). Appl Geochem 11:541-554. doi:10.1016/0883-2927(96)00010-8

Lett MC, Muller D, Lièvremont D, Silver S, Santini J (2012) Unified nomenclature for genes involved in prokaryotic aerobic arsenite oxidation. J Bacteriol 194:207-208. doi:10.1128/JB.06391-11

Leys NM, Ryngaert A, Bastiaens L, Verstraete W, Top EM, Springael D (2004) Occurrence and phylogenetic diversity of Sphingomonas strains in soils contaminated with polycyclic aromatic hydrocarbons. Appl Environ Microbiol 70:1944-1955. doi:10.1128/AEM.70.4.1944-1955.2004

Morin G, Juillot F, Casiot C, Bruneel O, Personné JC, Elbaz-Poulichet F et al (2003) Bacterial formation of tooeleite and mixed arsenic (III) or arsenic (V)-iron (III) gels in the Carnoules acid mine drainage, France. A XANES, XRD, and SEM study. Environ Sci Technol 37(9):1705-1712. doi:10.1021/ es025688p

Muller D, Médigue C, Koechler S, Barbe V, Barakat M, Talla E et al (2007) A tale of two oxidation states: bacterial colonization of arsenic-rich environments. PLoS Genet 3(4):e53. doi:10.1371/journal.pgen.0030053
Oremland RS, Stolz JF (2003) The ecology of arsenic. Science 300:939-944

Rawlings DE, Johnson DB (2007) The microbiology of biomining: development and optimization of mineral-oxidizing microbial consortia. Microbiology 153:315-324. doi:10.1099/mic.0.2006/001206-0

Remonsellez F, Galleguillos F, Moreno-Paz M, Parro V, Acosta M, Demergasso C (2009) Dynamic of active microorganisms inhabiting a bioleaching industrial heap of low-grade copper sulfide ore monitored by real-time PCR and oligonucleotide prokaryotic acidophile microarray. Microb Biotechnol 2(6):613-624. doi:10.1111/j.1751-7915.2009.00112.x

Rhine ED, Onesios KM, Serfes ME, Reinfelder JR, Young LY (2008) Arsenic transformation and mobilization from minerals by the arsenite oxidizing strain WAO. Environ Sci Technol 42:1423-1429. doi:10.1021/es071859k

Saitou N, Nei M (1987) The neighbor-joining method: a new method for reconstructing phylogenetic trees. Mol Biol Evol 4:406-425

Santini JM, Sly LI, Schnagl RD, Macy JM (2000) A new chemolithoautotrophic arsenite-oxidizing bacterium isolated from a gold mine: phylogenetic, physiological, and preliminary biochemical studies. Appl Environ Microbiol 66:92-97. doi:10.1128/AEM.66.1.92-97.2000

Shakya S, Pradhan B, Smith L, Shrestha J, Tuladhar S (2012) Isolation and characterization of aerobic culturable arsenic-resistant bacteria from surface water and groundwater of Rautahat District, Nepal. J Environ Manage 95:S20-S25. doi:10.1016/j.jenvman.2011.08.001

Slyemi D, Bonnefoy V (2012) How prokaryotes deal with arsenic. Environ Microbiol Rep 4(6):571-586. doi:10.1111/j.1758-2229.2011.00300.x

Tamura K, Nei M, Kumar S (2004) Prospects for inferring very large phylogenies by using the neighbor-joining method. Proc Natl Acad Sci USA 101:11030-11035. doi:10.1073/pnas.0404206101

Tamura K, Dudley J, Nei M, Kumar S (2007) MEGA 4: molecular evolutionary genetics analysis (MEGA) software version 4.0. Mol Biol Evol 24:696-1599. doi:10.1093/molbev/msm092

Travisany D, Genova A, Sepúlveda A, Bobadilla-Fazzini RA, Parada P, Maass A (2012) Draft genome sequence of the Sulfobacillus thermosulfidooxidans Cutipay strain, an indigenous bacterium isolated from a naturally extreme mining environment in northern Chile. J Bacteriol 194:6327-6328. doi:10.1128/JB.01622-12

Tuffin IM, Hecto SB, Deane SM, Rawlings DE (2006) Resistance determinants of a highly arsenic-resistant strain of Leptospirillum ferriphilum isolated from a commercial biooxidation tank. Appl Environ Microbiol 72:2247-2253. doi:10.1128/AEM.72.3.2247-2253.2006

van der Merwe JA, Deane SM, Rawlings DE (2010) The chromosomal arsenic resistance genes of Sulfobacillus thermosulfidooxidans. Hydrometallurgy 104:477-482. doi:10.1016/j.hydromet.2010.01.017

Watling HR, Perrot FA, Shiers DW (2008) Comparison of selected characteristics Sulfobacillus species and review of their occurrence in acidic and bioleaching environments. Hydrometallurgy 93:57-65. doi:10.1016/j. hydromet.2008.03.001

Xie J, He Z, Liu X, Liu X, van Nostrand JD, Deng Y et al (2011) GeoChip-based analysis of the functional gene diversity and metabolic potential of microbial communities in acid mine drainage. Appl Environ Microbiol 77:991-999. doi:10.1128/AEM.01798-10

\section{Submit your manuscript to a SpringerOpen ${ }^{\circ}$ journal and benefit from:}

- Convenient online submission

- Rigorous peer review

- Immediate publication on acceptance

- Open access: articles freely available online

- High visibility within the field

- Retaining the copyright to your article

Submit your next manuscript at $>$ springeropen.com 